\title{
Improved Understanding of Electricity Concept and Creativity of Students with PjBL-C Learning Model (Project Based Learning Community)
}

\author{
Peningkatan Pemahaman Konsep Kelistrikan dan Kreativitas Peserta Didik Melalui \\ Model Pembelajaran Pjbl-C (Project Based Learning Community)
}

\author{
Bambang Surahmadi $(*)$ \\ SMP Negeri 1 Temanggung \\ Jl. Kartini No.17 Temanggung, Jawa Tengah
}

Received: April 5, 2018

Revised: July 10, 2018

Accepted: July 11, 2018

\begin{abstract}
This study aims to improve understanding of electricity concept and creativity of learners through the model of learning PjBL-C. Project-based learning is a learning model involving learners in problem solving and other meaningful task assignments, resulting in a project or product in understanding learning. PjBL-C is a collaborative $\mathrm{PjBL}$ and community (community) where learners learn directly on BTL (Bureau of Electrical Engineering). Subjects in this study were students of class IX-A SMP Negeri 1 Temanggung, amounting to 30 students. This form of research is a classroom action research as much as two cycles. Each cycle consists of 4 stages: planning, action implementation, observation, and reflection. Data analysis technique used is descriptive analysis model. Data collection methods used were observation and test. The result of his research shows that the learning model of PjBL-C can improve the students' understanding of the concept of IX-A students of SMP Negeri 1 Temanggung. This is evidenced by the percentage of learning completeness of students that before the action is given to cycle 1 is increased $16 \%$, increase from cycle I to cycle II by $44 \%$, and increase from beginning to cycle II by $60 \%$. PjBL-C learning model can also improve the creativity of students of class IX-A SMP Negeri 1 Temanggung. This is evidenced by the percentage of the average value of learners is the increase from cycle I to cycle II by $30 \%$. The conclusion of this research is through the use of model PjBL-C can improve understanding of electric concept and creativity of learners.

Keywords: Creativity, understanding of electricity concept, project based learning, community.
\end{abstract}

(*) Corresponding Author: $\quad$ masba 25@yahoo.co.id, hp: 085878880273.

How to Cite: Surahmadi, B. (2018). Improved understanding of electricity concept and creativity of students with pjbl-c learning model (project based learning community). Formatif: Jurnal Ilmiah Pendidikan MIPA, 8 (2): 81-90. http://dx.doi.org/10.30998/formatif.v8i2.2443

\section{PENDAHULUAN}

Fisika merupakan rangkaian materi dalam ruang lingkup IPA. Fisika adalah salah satu ilmu yang paling dasar dari ilmu pengetahuan (Young \& Freedman, 2004). Dalam praktiknya, ternyata pembelajaran fisika di beberapa sekolah tidak selalu sesuai dengan harapan tersebut. SMP Negeri 1 Temanggung merupakan salah satu sekolah favorit di Kabupaten temanggung yang memiliki nilai input yang bagus. Akan tetapi, dalam 
Formatif: Jurnal Ilmiah Pendidikan MIPA

Vol. 8, No. 2, Agustus 2018, pp. 81-90

p-ISSN: 2088-351X

e-ISSN: 2502-5457

DOI: http://dx.doi.org/10.30998/formatif.v8i2.2443

kenyataannya masih terdapat beberapa permasalahan yang terjadi dalam proses belajar di kelas IX. Peserta didik cenderung pasif pada saat pembelajaran, misalnya ketika guru bertanya hanya ada empat orang peserta didik yang mau menjawab sedangkan peserta didik lainnya ada yang melamun, mencorat-coret kertas, dan mengobrol. Kemudian ketika guru memberikan latihan soal hanya ada beberapa peserta didik yang mengerjakan sendiri, sedangkan yang lainnya menyalin hasil pekerjaan temannya dan bahkan ada yang tidak mengerjakannya sama sekali. Selain itu hasil belajar peserta didik juga cenderung rendah, khususnya dalam materi yang berkaitan dengan fisika. Sebagai gambaran, dari hasil nilai harian sebelum perlakuan, pada materi listrik statis terlihat banyak peserta didik yang belum tuntas KKM.

Dengan demikian, dalam mempelajari fisika tidak hanya dibutuhkan kemampuan memahami. Namun, dibutuhkan kemampuan untuk mengamati, mengukur, maupun menganalisis hukum-hukum fisika. Pada kenyataannya kemampuan untuk menganalisis sesuatu materi fisika tidak semudah hanya memahaminya saja. Soal fisika menuntut kemampuan siswa dalam menggunakan logika berpikirnya dalam menjawab, mengerjakan atau menyelesaikan soal-soal fisika. Siswa yang memiliki logika berpikir yang baik, akan dapat menangkap pokok permasalahan dalam setiap butir soal (Bhakti \& Napis, 2017).

Peserta didik cenderung mengalami kesulitan dalam menguraikan sesuatu materi fisika yang disebabkan oleh kurangnya kemampuan peserta didik dalam menganalisis rumus maupun hukum fisika. Kebanyakan dari peserta didik yang telah mampu memahami materi yang diterangkan guru, akan mengalami kesulitan jika diberikan soal yang berbeda dengan contoh soal yang sudah ada. Anggapan sulit yang tertanam pada peserta didik akan mengakibatkan sikap malas peserta didik untuk mempelajari fisika lebih mendalam. Dengan demikian guru sebaiknya membiasakan diri untuk senantiasa melatih peserta didik dalam menganalisis suatu permasalahan fisika. Dengan membiasakan peserta didik untuk menganalisis rumus-rumus fisika, peserta didik akan lebih mudah dalam menyelesaikan soal-soal yang berkaitan dengan analisis rumus dan perhitungan.

Banyak hal terjadi di alam yang dapat diterangkan dengan konsep fisika sederhana. Namun sampai sekarang masih banyak peserta didik yang beranggapan bahwa fisika merupakan pelajaran yang paling sulit di antara mata pelajaran lainnya. Hal tersebut tampak pada kurangnya perhatian dan minat peserta didik pada mata pelajaran fisika atau IPA yang berdampak pada sikap peserta didik yang cenderung pasif pada kegiatan pembelajaran di kelas. Maka dari itu perlu adanya tindakan dari seorang guru dalam mengubah pandangan peserta didik tentang sulitnya mata pelajaran fisika.

Sesuai dengan pendekatan yang digunakan dalam Kurikulum 2013, peserta didik diberanikan untuk mencari sumber belajar lain yang tersedia dan terbentang luas di sekitarnya. Peran guru sangat penting untuk meningkatkan dan menyesuaikan daya serap peserta didik dengan ketersediaan kegiatan pada buku. Guru dapat memperkayanya dengan kreasi dalam bentuk kegiatan-kegiatan lain yang sesuai dan relevan yang bersumber dari lingkungan sosial dan alam.

Oleh karena itu dalam membelajarkan IPA kepada peserta didik, guru hendaknya lebih memilih berbagai variasi pendekatan, strategi, maupun model yang sesuai dengan situasi sehingga tujuan pembelajaran yang direncanakan akan tercapai (Bhakti \& Astuti, 2018). Perlu diketahui bahwa baik atau tidaknya suatu pemilihan model pembelajaran akan tergantung tujuan pembelajarannya, kesesuaian dengan materi pembelajaran, tingkat perkembangan peserta didik, kemampuan guru dalam mengelola pembelajaran serta mengoptimalkan sumber-sumber belajar yang ada. Hal ini sesuai dengan pendapat Leonard \& Chaidir (2018) yang mengatakan keberhasilan pelaksanaan pembelajaran 
Formatif: Jurnal Ilmiah Pendidikan MIPA

Vol. 8, No. 2, Agustus 2018, pp. 81-90

p-ISSN: 2088-351X

e-ISSN: $2502-5457$

DOI: http://dx.doi.org/10.30998/formatif.v8i2.2443

sangat bergantung pada sejauh mana pembelajaran itu didesain atau direncanakan... juga dinilai dari apa yang telah diperoleh siswa dalam pembelajaran, apakah telah memenuhi tujuan yang diinginkan atau belum.

Kurangnya kemampuan pemahaman konsep peserta didik juga terlihat pada saat sebelum KBM dimulai. Peserta didik diberikan pertanyaan mengenai materi yang telah dipelajari sebelumnya, peserta didik belum dapat menjawab pertanyaan tersebut dengan tepat. Peserta didik yang memiliki kemampuan pemahaman konsep akan mempelajari materi yang telah diterima dengan lebih mendalam dan sungguh-sungguh. Ketika akan menerima materi selanjutnya, peserta didik sudah memahami materi yang telah diberikan oleh guru. Kurangnya kemampuan pemahaman konsep peserta didik ini, menumbuhkan keinginan peneliti untuk mengembangkan kemampuan pemahaman konsep peserta didik. Pemahaman merupakan landasan bagi peserta didik untuk membangun wawasan (Simanjuntak, 2012). Dalam pembelajaran IPA lebih menekankan pada konsep. Dengan demikian artinya dalam mempelajari IPA peserta didik harus memahami konsep IPA terlebih dahulu agar dapat menyelesaikan soal-soal dan mampu mengaplikasikan pembelajaran tersebut dalam dunia nyata (Astuti \& Dasmo, 2016).

Peserta didik juga belum bisa mandiri dan mengeksplore pemahaman konsep setelah mendapatkan materi dari guru kreativitas peserta didik belum terlihat. Guru harus mengubah metode pembelajaran di kelas agar bisa menumbuhkan kreativitas peserta didik dalam memahami konsep fisika. Dengan kreativitas maka akan menghasilkan sikap psikomotorik peserta didik yang lebih kreatif dan mampu berpikir kritis dalam menghadapi persoalan sains dalam sehari-hari (Astuti, 2016). Dalam suatu proses pembelajaran peran guru di sekolah dan motivasi belajar peserta didik yang tinggi akan sangat membantu peserta didiknya dalam mencapai hasil belajar yang optimal. Kurangnya motivasi guru dalam menarik perhatian peserta didik selama pembelajaran berlangsung akan mempengaruhi hasil belajar.

Faktor inilah yang menjadi penyebab masih rendahnya peserta didik yang belum tuntas belajar, yaitu proses pembelajaran yang belum optimal dan motivasi yang dilakukan oleh guru maupun peserta didik masih kurang. Guru belum mengembangkan strategi pembelajaran berbasis masalah untuk membuat suasana di dalam kelas nyaman sehingga peserta didik perlu dilibatkan dalam pemahaman konsep dengan harapan peserta didik mampu meningkatkan prestasi belajar pada umunya. Meningkatkan kemampuan pemahaman konsep dan motivasi belajar peserta didik perlu dilakukan pembelajaran IPA dengan pendekatan keterampilan proses.

Pada kurikulum 2013 menggunakan strategi pembelajaran scientifict yang menuntut peserta didik harus lebih mandiri, karena pembelajaran yang dilakukan bersifat student center (berpusat pada siswa). Konsep listrik merupakan salah satu materi Fisika yang terdapat pada peserta didik kelas IX SMP. Berdasarkan wawancara beberapa peserta didik kelas IX SMP Negeri 1 Temanggung menyimpulkan bahwa mayoritas peserta didik tidak menyukai materi kelistrikan karena rumusnya yang susah dan tidak bisa memahami konsep dengan baik. Dalam tindak lanjut pemahaman konsep IPA peserta didik pada materi kelistrikan akan dilakukan suatu inovasi pembelajaran yang bisa membawa peserta didik dalam lingkungan masyarakat untuk bisa belajar lebih lanjut tentang seluk beluk listrik dalam kehidupan sehari-hari.

Upaya yang akan ditempuh untuk meningkatkan pemahaman konsep dan kreativitas peserta didik dapat melalui pendekatan PjBL-C (Project Based Learning Community). Project Based Learning adalah suatu model pembelajaran yang melibatkan suatu proyek dalam proses pembelajaran (Wena, 2011). Pembelajaran berbasis proyek terdiri dari proyek yang mengintegrasikan ilmu pengetahuan, teknologi, masyarakat, sejarah, matematika, politik, dan kesempatan diskusi produktif untuk siswa, mendorong 
Formatif: Jurnal Ilmiah Pendidikan MIPA

Vol. 8, No. 2, Agustus 2018, pp. 81-90

p-ISSN: 2088-351X

e-ISSN: 2502-5457

DOI: http://dx.doi.org/10.30998/formatif.v8i2.2443

penyelidikan siswa diarahkan masalah dunia nyata. Memberikan mereka semangat belajar dan pengajaran menjadi efektif (Munawaroh et al, 2012). Akan tetapi, menurut Mahanal et al (2010) pembelajaran berbasis proyek atau Project Based Learning (PBL) adalah suatu pembelajaran yang didesain untuk persoalan yang kompleks yang mana siswa melakukan investigasi untuk memahaminya, menekankan pembelajaran dengan aktivitas yang lama, tugas yang diberikan pada siswa bersifat multidisiplin, berorientasi pada produk.

Proyek yang dikerjakan oleh peserta didik dapat berupa proyek kelompok yang berhubungan dengan materi listrik dinamis yang bertujuan untuk meningatkan pemahaman konsep listrik dinamis dan kreativitas peserta didik. Proyek tersebut dilaksanakan dalam jangka waktu tertentu secara kolaboratif, menghasilkan sebuah produk, yang hasilnya kemudian akan ditampilkan atau dipresentasikan. PjBL-C merupakan kolaborasi antara model pembelajaran $\mathrm{PjBL}$ yang berbasis masyarakat. Peserta didik dibawa ke dalam kehidupan sehari-hari yang menyangkut materi kelistrikan yaitu pada BTL (Biro Teknik Listrik). Pada pembelajaran PjBL-C kegiatan pembelajarannya berlangsung secara kolaboratif dalam kelompok yang heterogen. Berdasarkan latar belakang masalah di atas, peneliti melakukan Penelitian Tindakan Kelas (PTK) yang berjudul "Peningkatan Pemahaman Konsep Kelistrikan dan Kreativitas Peserta Didik Melalui Model Pembelajaran PjBL-C (Project Based Learning) Kelas IX-A SMP Negeri 1 Temanggung."

\section{METODE}

Penelitian ini merupakan penelitian tindakan kelas (PTK) yang dilaksanakan di SMP Negeri 1 Temanggung pada tahun ajaran 2015/2016. Subjek dalam penelitian ini adalah peserta didik kelas IX-A SMP Negeri 1 Temanggung semester genap tahun ajaran 2015/2016 yang berjumlah 30 peserta didik, yang terdiri dari 12 peserta didik laki-laki dan 17 peserta didik perempuan.

Instrumen yang digunakan pada penelitian ini adalah lembar observasi aktivitas siswa, lembar observasi aktivitas guru, dan lembar soal postest. Metode yang digunakan dalam penelitian ini adalah metode dokumentasi, metode observasi, dan metode tes.

Pada gambar 1 merupakan siklus pelaksanaan PTK yang terdiri dari perencanaan, pelaksanaan, observasi, dan refleksi. Pada tahap perencanaan yang dilakukan adalah melakukan observasi awal untuk mengidentifikasi masalah yang dihadapi peserta didik. Identifikasi masalah yang dihadapi peserta didik dengan melihat nilai UAS (Ujian Akhir Sekolah) gasal untuk mata pelajaran IPA, menyusun skenario pembelajaran yang meliputi pembuatan RPP (Rencana Pelaksanaan Pembelajaran) materi listrik dinamis sesuai silabus IPA Kelas IX SMP Negeri 1 Temanggung, menyusun tes evaluasi untuk menilai pemahaman konsep, menyusun lembar observasi yang digunakan untuk menilai kreativitas peserta didik, aktivitas guru, dan aktivitas peserta didik, menyiapkan alat dan bahan yang akan digunakan untuk kerja proyek. Kegiatan pada tahap pelaksanaan adalah melaksanakan skenario pembelajaran dengan menerapkan model pembelajaran PjBL-C sesuai dengan perencanaan pada RPP. Tindakan yang dilakukan guru adalah mengorganisasikan peserta didik dalam pembagian kelompok, mengarahkan peserta didik untuk terjun secara langsung dalam lingkungan masyarakat yaitu berkunjung ke BTL (Biro Teknik Listrik) terdekat.

Setelah mendapatkan pengalaman langsung di luar, kemudian guru membimbing pelaksanaan kerja proyek, diskusi peserta didik, menganalisis, dan mengevaluasi hasil presentasi kelompok. Dalam kegiatan pembelajaran peserta didik membuat alat sendiri 
Formatif: Jurnal Ilmiah Pendidikan MIPA

Vol. 8, No. 2, Agustus 2018, pp. 81-90

p-ISSN: 2088-351X

e-ISSN: 2502-5457

DOI: http://dx.doi.org/10.30998/formatif.v8i2.2443

dan diaplikasikan dalam kehidupan sehari-hari. Kemudian guru melihat kreativitas peserta didik yang dinilai pada lembar observasi. Di setiap akhir siklus, guru memberikan tes untuk mengetahui hasil belajar kognitif peserta didik. Tes yang diberikan berbentuk tes pilihan ganda.

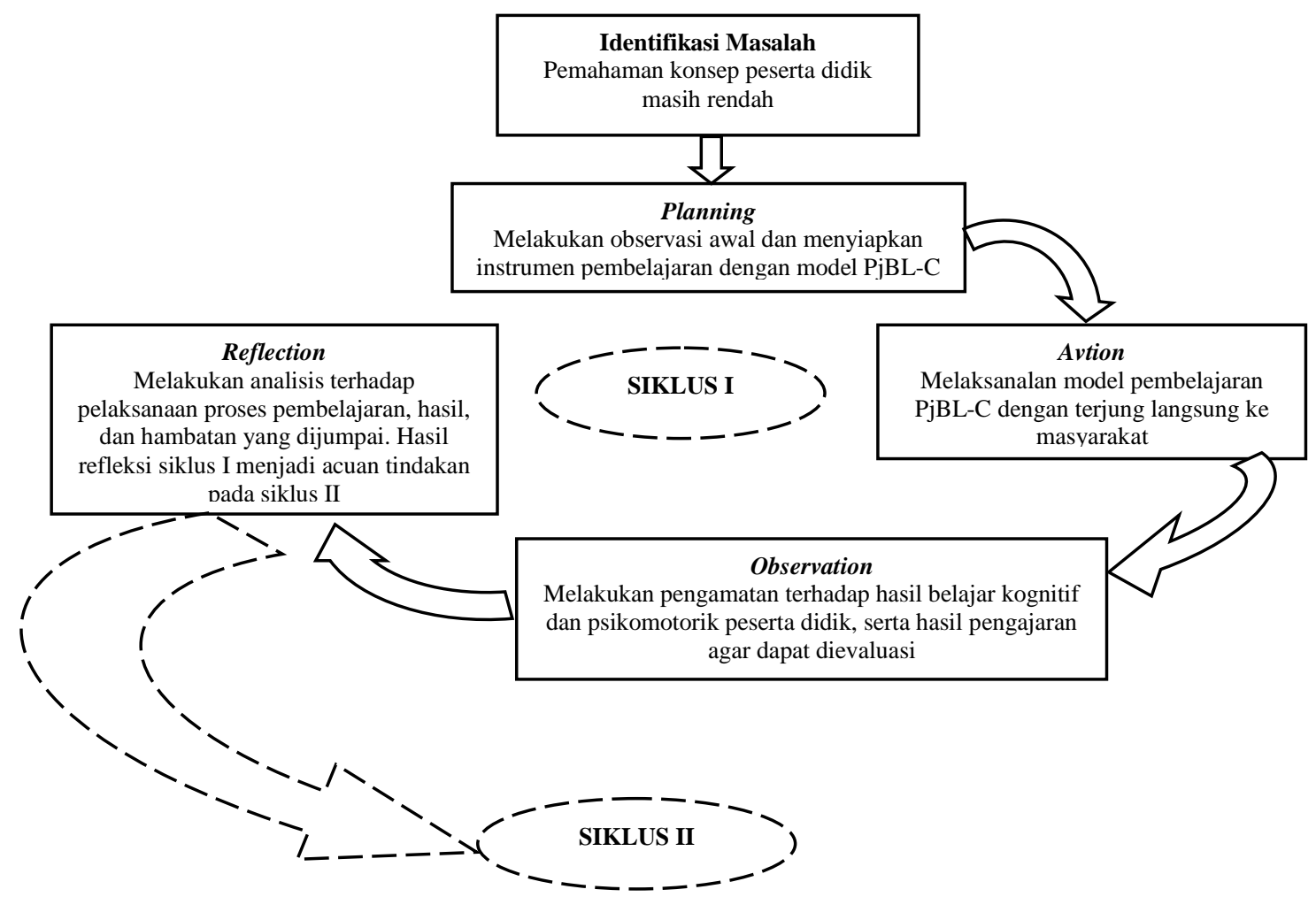

Gambar 1. Siklus Pelaksanaan PTK

Kegiatan pada tahap observasi yaitu menilai hasil tes evaluasi peserta didik untuk mengetahui pemahaman konsep peserta didik setelah proses pembelajaran. Kreativitas peserta didik dilihat dari hasil karya proyek yang dibuat peserta didik dengan kelompoknya. Selain itu juga melakukan pengamatan terhadap jalannya proses pembelajaran pada melalui lembar observasi selama proses pembelajaran berlangsung. Tujuannya untuk mengetahui sejauh mana efek tindakan pembelajaran dengan menerapkan model pembelajaran PjBL-C. pada tahap terakhr yaitu refleksi. Semua data yang diperoleh dari pelaksanaan dan proses observasi dikumpulkan, dianalisis, dan dievaluasi untuk mengetahui berhasil atau tidaknya tindakan yang dilakukan. Hasil refleksi ini dijadikan acuan untuk memperbaiki kinerja dan melakukan revisi terhadap perencanaan yang akan dilaksanakan pada siklus berikutnya.

Untuk mengetahui ketuntasan belajar peserta didik digunakan rumus:

$$
K B=\frac{T}{T t} \times 100 \%
$$

Keterangan:

$K B$ : Ketuntasan belajar

$T$ : Jumlah peserta didik yang tuntas belajar

$T t$ : Jumlah seluruh peserta didik 
Formatif: Jurnal Ilmiah Pendidikan MIPA

Vol. 8, No. 2, Agustus 2018, pp. 81-90

p-ISSN: 2088-351X

e-ISSN: 2502-5457

DOI: http://dx.doi.org/10.30998/formatif.v8i2.2443

Tabel 1. Kiteria Ketuntasan Belajar Peserta Didik

\begin{tabular}{cc}
\hline Interval Skor & Kategori \\
\hline Nilai $\leq 80$ & peserta didik tidak tuntas belajar \\
Nilai $\geq 80$ & peserta didik tuntas belajar \\
\hline
\end{tabular}

Penilaian kreativitas peserta didik tiap aspek yang diamati dalam menggunakan rumus:

$$
K R(\%)=\frac{n}{N} \times 100 \%
$$

Keterangan:

$n=$ Jumlah poin karakteristik peserta didik

$N=$ Jumlah seluruh peserta didik

Tabel 2. Kriteria Kreativitas Belajar Peserta Didik

\begin{tabular}{cc}
\hline Interval Skor & Kategori \\
\hline $0 \% \leq K R<25 \%$ & Kurang baik \\
$25 \% \leq K R<50 \%$ & Cukup baik \\
$50 \% \leq N R S<75 \%$ & Baik \\
$75 \% \leq N R S<100 \%$ & Sangat baik \\
\hline
\end{tabular}

\section{HASIL DAN PEMBAHASAN}

Hasil

Hasil pemahaman konsep peserta didik kelas IX-A pada materi listrik dinamis dengan 30 peserta didik pada siklus I diperoleh nilai tertinggi 88 , nilai terendah 68 , dan nilai rata-rata 78. Dari hasil tersebut diperoleh persentase ketuntasan belajar pemahaman konsep fisika sebesar 53\%. Hal ini belum sesuai dengan taraf ketuntasan belajar yaitu $>85 \%$. Nilai rata-rata peserta didik pada siklus I juga belum sesuai dengan batas tuntas KKM. Oleh karena itu perlu dilakukan refleksi.

Kreativitas peserta didik pada siklus I masih rendah dan belum mulai terlihat. Dari 30 peserta didik hanya 18 yang sudah melebihi nilai KKM pada aspek kreativitas peserta didik. Rata-rata kreativitas peserta didik hanya 77. Hal ini juga menunjukkan bahwa sebagian peserta didik belum tuntas KKM. Kenyataanya pada saat peserta didik membuat proyek masih ada peserta didik yang tidak serius dalam membuat suatu proyek sehingga akan mempengaruhi teman satu kelompoknya. Peserta didik belum terlihat mandiri dan mempunyai ide kreatif.

Kenyataan pemahaman konsep dan kreativitas peserta didik di atas menunjukkan bahwa perlu ada perbaikan (refleksi) secara menyeluruh pada proses pembelajaran IPA dengan model pembelajaran PjBL-C, karena pemahaman konsep yang diperoleh peserta didik belum optimal. Penyebab kurang optimal proses dan hasil belajar berdasarkan pengamatan salah satunya adalah pada kondisi awal rata-rata peserta didik pada saat mendengarkan penjelasan guru, mencatat penjelasan, serta sebagai proses pembelajaran masih minim sehingga materi pelajaran belum dapat dipahami peserta didik dengan baik. Pada saat refleksi telah dilakukan penjelasan ulang dengan harapan pada siklus kedua kondisi awal peserta didik sudah siap mengikuti pelajaran dengan model pembelajaran PjBL. Tugas proyek yang dikerjakan secara berkelompok untuk menunjukkan kretivitas peserta didik juga belum dikerjakan secara maksimal. Dari satu kelompok hanya ada satu 
Formatif: Jurnal Ilmiah Pendidikan MIPA

Vol. 8, No. 2, Agustus 2018, pp. 81-90

p-ISSN: 2088-351X

e-ISSN: 2502-5457

DOI: http://dx.doi.org/10.30998/formatif.v8i2.2443

atau dua orang saja yang aktif mengerjakan tugas kelompok. Refleksi meningkatkan kerja kelompok dalam mengerjakan tugas proyek.

Hasil pemahaman konsep peserta didik kelas IX-A pada materi listrik dinamis dengan 30 peserta didik pada siklus II yang diperoleh adalah nilai tertinggi 96 , nilai terendah 76, dan nilai rata-rata 76. Dari hasil di atas diperoleh persentase ketuntasan belajar peserta didik dalam pemahaman konsep fisika pada materi listrik sebesar 97\%. Ini menunjukkan bahwa pemahaman peserta didik pada siklus II sudah meningkat. Nilai ratarata peserta didik juga sudah melebihi KKM dan meningkat dari siklus I.

Tabel 3. Hasil Pemahaman Konsep IPA

\begin{tabular}{lccc}
\hline & $\begin{array}{c}\text { Sebelum } \\
\text { perlakuan }\end{array}$ & Siklus I & Siklus II \\
\hline Nilai terendah & 53 & 68 & 76 \\
Nilai tertinggi & 83 & 88 & 96 \\
Rata-rata & 74 & 78 & 84 \\
Jumlah nilai < KKM & 19 & 16 & 1 \\
Jumlah nilai > KKM & 11 & 14 & 29 \\
Persentase ketuntasan belajar & $37 \%$ & $28 \%$ & $97 \%$ \\
\hline
\end{tabular}

Kreativitas peserta didik pada siklus II juga sudah menunjukkan nilai yang bagus. Dari analisis data diperoleh nilai rata-rata kreativitas peserta didik sebesar 84 dan persentase ketuntasan kreativitas peserta didik sebesar 90\%. Pada siklus II peserta didik sudah terllihat aktif dan mandiri dalam mengerjakan tugas proyek. Kekompakkan dalam kelompoknya juga sudah muncul. Antar kelompok saling mendukung dan bekerjasama dalam menghasilkan suatu karya yang baik.

Tabel 4. Nilai Kreativitas Peserta Didik

\begin{tabular}{lcc}
\hline & Siklus I & Siklus II \\
\hline Nilai terendah & 65 & 76 \\
Nilai tertinggi & 85 & 89 \\
Rata-rata & 77 & 84 \\
Jumlah nilai < KKM & 18 & 3 \\
Jumlah nilai > KKM & 12 & 27 \\
Persentase ketuntasan kreativitas & $60 \%$ & $90 \%$ \\
\hline
\end{tabular}

\section{Pembahasan}

Pembelajaran berbasis proyek memuat tugas-tugas kompleks yang berdasarkan pada pertanyaan-pertanyaan, permasalahan yang menantang, dan menuntut siswa untuk dapat merancang, memecahkan masalah, membuat keputusan, melakukan kegiatan investigasi, serta memberikan kesempatan peserta didik bekerja secara mandiri (Wena, 2011). Sehingga pada akhirnya, kemampuan peserta didik dalam memecahkan masalah da-pat meningkat seiring dengan terselesaikannya proyek tersebut.

Data yang diperoleh dari prasiklus, siklus I dan siklus II dikaji sesuai dengan rumusan masalah, kemudian dikaitkan dengan teori-teori yang telah dikemukakan. Berdasarkan hasil observasi, tes, dan analisis data yang dilakukan, ditemukan adanya peningkatan nilai pemahaman konsep materi listrik dinamis pada peserta didik kelas IX-A tahun ajaran 2015/2016 pada setiap siklus. 
Formatif: Jurnal Ilmiah Pendidikan MIPA

Vol. 8, No. 2, Agustus 2018, pp. 81-90

p-ISSN: 2088-351X

e-ISSN: 2502-5457

DOI: http://dx.doi.org/10.30998/formatif.v8i2.2443

Siklus I dilaksanakan dalam dua pertemuan yaitu pertemuan I pada tanggal 28 Oktober 2015. Pada pertemuan pertama guru menjelaskan tujuan pembelajaran dan menjelaskan sedikit topik materi listrik dinamis, kemudian peserta didik membagi peserta didik dalam enam kelompok. Satu kelompok terdiri dari lima peserta didik. Pembagian kelompok peserta didik berdasarkan nomor urut atau presensi agar tidak terjadi kesenjangan antar peserta didik. Kemudian setelah itu peserta didik mebuat proyek menjabarkan dari konsep yang sudah dipahami oleh peserta didik. Pertemuan kedua dilaksanakan pada tanggal 30 Oktober 2015. Proses KBM masih melanjutkan membuat proyek dan setelah selesai mempresentasikan di depan kelas terhadap hasil karya dari masing-masing kelompok. Tes evaluasi siklus I dilaksanakan pada tanggal 4 November 2015, yang bertujuan untuk mengukur pemahaman konsep peserta didik terhadap materi listrik dinamis. Selama proses pembelajaran berlangsung, kreativitas peserta didik dalam membuat proyek juga dinilai oleh guru melalui lembar observasi.

Setelah dilaksanakan tindakan pada siklus I, yaitu dengan menggunakan model PJBL-C dalam kegiatan pembelajaran IPA materi kelistrikan menunjukkan adanya peningkatan nilai evaluasi dari sebelum diberi perlakuan. Dapat dilihat dari peningkatan ketuntasan klasikal, yaitu sebesar 53\%. Dari 30 peserta didik, sebanyak 16 peserta didik yang memperoleh nilai $\geq 80$. Nilai rata-rata kelas juga meningkat menjadi 78 . Tetapi nilai ini belum memenuhi batas tuntas KKM (batas KKM=80), sehingga dilakukan refleksi utuk dilanjutkan penelitian lagi pada siklus II.

Pada aspek kreativitas peserta didik dalam siklus I, interaksi dan partisipasi peserta didik dalam diskusi masih dipengaruhi oleh kemampuan kognitif dan jenis kelamin peserta didik. Peserta didik yang kemampuan kognitifnya lebih tinggi dan berjenis kelamin perempuan cenderung lebih aktif di kelas. Dalam mengerjakan tugas proyek juga hanya ada dua orang yang aktif dalam kelompoknya, sedangkan peserta didik yang lain hanya melihat saja.

Siklus II dilaksanakan dalam dua pertemuan yaitu pertemuan pada tanggal 11 dan 13 November 2015. Pada pertemuan pertama guru mengajak peserta didik untuk terjun ke masyarakat melihat secara langsung ke BTL (Biro Teknik Listrik), kemudian peserta didik belajar dan langsung berinteraksi dengan masyarakat. Konsep yang peserta didik dapat dari kegiatan ini bertujuan untuk memahami ragkaian dasar listrik yaitu rangkaian seri dan paralel. Kemudian setelah itu peserta didik membuat proyek menjabarkan dari konsep yang sudah dipahami oleh peserta didik. Pertemuan kedua dilanjutkan pembelajaran dalam membuat proyek dan diskusi kelompok. Pada saat membuat tugas proyek peserta didik sudah mulai terlihat aktif dalam kelompoknya dan berperan saling bekerja sama dalam membuat hasil karya yang bagus. Evaluasi siklus II dilaksanakan pada tanggal 18 November 2015.

Setelah dilaksanakan tindakan pada siklus II, yaitu dengan menggunakan model PjBL-C dalam kegiatan pembelajaran IPA materi kelistrikan menunjukkan adanya peningkatan nilai evaluasi dari siklus I ke siklus II. Dapat dilihat dari peningkatan ketuntasan klasikal, yaitu sebesar 97\%. Dari 30 peserta didik, sebanyak 29 peserta didik yang memperoleh nilai $\geq 80$. Nilai rata-rata kelas juga meningkat menjadi 84 . Hal ini menunjukkan proses pembelajaran PjBL-C dapat meningkatkan pemahaman konsep peserta didik kelas IX-A pada materi listrik dinamis.

Sejalan dengan penelitian Yance et al (2013) bahwa PBL merupakan model pembelajaran yang dapat mengaktifkan peserta didik dalam belajar. Peserta didik dibiasakan untuk menemukan sendiri konsep fisika melalui proyek yang diberikan dengan mengonstruksi pengetahuan dalam diri peserta didik. Mereka diberi kebebasan untuk mencari sumber yang dapat membantu proyek baik itu melalui studi pustaka ataupun bertanya kepada guru fisika lain di luar jam pelajaran. Selain itu, kemampuan 
Formatif: Jurnal Ilmiah Pendidikan MIPA

Vol. 8, No. 2, Agustus 2018, pp. 81-90

p-ISSN: 2088-351X

e-ISSN: 2502-5457

DOI: http://dx.doi.org/10.30998/formatif.v8i2.2443

sosial peserta didik juga dikembangkan melalui diskusi dan kerjasama dalam kelompok sehingga peserta didik terlatih untuk menghargai teman, menanggapi pendapat orang lain dengan baik, serta mampu berbicara di depan orang banyak melalui presentasi laporan hasil poyek. PBL juga meningkatkan kreativitas peserta didik dalam menghasilkan produk dari proyek yang mereka kerjakan.

Oleh karena itu, jelaslah alasan mengapa PBL dapat meningkatkan hasil belajar fisika peserta didik pada ketiga ranah. Kegiatan yang terselenggara melalui pembelajaran berbasis proyek dirasa mampu memberikan konstribusi terhadap perkembangan kemahiran generik sains peserta didik (Luthvitasari et al, 2012). Menurut Purnomo \& Mawarsari (2014) Project Based Learning (PBL) adalah sebuah model atau pendekatan pembelajaran yang inovatif, yang menekankan belajar kontekstual melalui kegiatankegiatan yang kompleks. Pembelajaran berbasis proyek adalah sebuah pembelajaran yang relevan dengan melibatkan aspek lingkungan tempat peserta didik berada dan belajar dengan melibatkan kreativitas yang ada dalam diri peserta didik (Widiyatmoko \& Pamelasari, 2012).

Antara pemahaman konsep dan kreativitas saling keterkaitan yang melekat pada peserta didik. Pemahaman mengacu pada kemampuan memahami makna materi yang telah dipelajari, unsur pemahaman ini pada dasarnya menyangkut kemampuan menangkap suatu makna konsep yang ditandai antara lain dengan kemampuan menjelaskan arti suatu konsep dengan kata-kata sendiri (Kurniawan, 2013). Kreativitas adalah hasil dari pemikiran kreatif. Oleh karena itu, hendaknya sistem pendidikan dapat merangsang pemikiran logis dan penalaran (Sambada, 2012). Dari sini dapat diprediksi bahwa kreativitas menentukan hasil belajar. Kreativitas peserta didik tidak hanya dilihat dari kemampuannya dalam membuat sesuatu, tetapi dari prosesnya itu yang dinamakan dengan keterampilan proses sains yang mampu mengintegrasi kemampuan peserta didik sehingga dinyatakan berkreatif (Ahmad \& Astuti, 2017).

\section{PENUTUP}

Berdasarkan hasil dan pembahasan pada penelitian tindakan kelas (PTK) yang telah diuraikan, maka dapat diperoleh simpulan sebagai berikut (1) Model pembelajaran PjBL-C dapat meningkatkan pemahaman konsep kelistrikan peserta didik kelas IX-A SMP Negeri 1 Temanggung. Hal tersebut dibuktikan dengan persentase ketuntasan belajar peserta didik yaitu sebelum diberi tindakan ke siklus 1 terjadi peningkatan $16 \%$, peningkatan dari siklus I ke siklus II sebesar $44 \%$, dan peningkatan dari awal sampai ke siklus II sebesar 60 \%. (2) Model pembelajaran PjBL-C dapat meningkatkan kreativitas peserta didik kelas IX-A SMP Negeri 1 Temanggung. Hal tersebut dibuktikan dengan persentase nilai rata-rata peserta didik yaitu peningkatan dari siklus I ke siklus II sebesar $30 \%$.

\section{DAFTAR PUSTAKA}

Ahmad, D.N., \& Astuti, I. A. D. (2017). Pengaruh pendekatan pembelajaran keterampilan proses dengan model pembelajaran problem based instruction terhadap peningkatan kemampuan berpikir kritis mahasiswa pada mata kuliah pendidikan kependudukan dan lingkungan hidup (PKLH). BIOMA Jurnal Ilmiah Biologi, 6(2), 57-65. http://dx.doi.org/10.26877/bioma.v6i2.1537. 
Astuti, I. A. D. (2016). Peningkatan kemampuan berpikir kritis mahasiswa melalui model pembelajaran problem based instruction (PBI) pada mata kuliah filsafat sains. Jurnal Pendidikan Fisika, 4(2), 68-75.

Astuti, I. A. D \& Dasmo. (2016). Upaya meningkatkan motivasi belajar dan pemahaman konsep IPA peserta didik dengan model pembelajaran problem posing. Jurnal Riset dan Kajian Pendidikan Fisika, 3(2), 39-44. http://dx.doi.org/10.12928/jrkpf.v3i2.5143.

Bhakti, Y. B., \& Astuti, I.A.D. (2018). The influence process of science skill and motivation learning with creativity learn. Journal of Education and Learning, 12(1), 30-35. http://dx.doi.org/10.11591/edulearn.v12i1.6912.

Bhakti, Y. B., \& Napis, N. (2017). Kemampuan mahasiswa pendidikan fisika dalam menyelesaikan soal ujian nasional fisika SMA ditinjau dari daerah sekolah asal. Jurnal Riset dan Kajian Pendidikan Fisika, 4(1), 25-30. http://dx.doi.org/10.12928/jrkpf.v4i1.6467.

Kurniawan, A. D. (2013). Metode inkuiri terbimbing dalam pembuatan media pembelajaran biologi untuk meningkatkan pemahaman konsep dan kreativitas siswa SMP. Jurnal Pendidikan IPA Indonesia, 2(1).

Leonard \& Chaidir, M. (2018). The development of learning design on down syndrome children's number recognition. Formatif: Jurnal Ilmiah Pendidikan MIPA, 8 (1): 17-30. http://dx.doi.org/10.30998/formatif.v8i1.2285.

Luthvitasari, N., \& Linuwih, S. (2012). Implementasi pembelajaran fisika berbasis proyek terhadap keterampilan berpikir kritis, berpikir kreatif dan kemahiran generik sains. Journal of Innovative Science Education, 1(2).

Mahanal, S., Darmawan, E., Corebima, A. D., \& Zubaidah, S. (2010). Pengaruh pembelajaran project based learning (PjBL) pada materi ekosistem terhadap sikap dan hasil belajar siswa SMAN 2 Malang. BIOEDUKASI (Jurnal Pendidikan Biologi), 1(1). http://dx.doi.org/10.24127/bioedukasi.v1i1.179

Munawaroh, R., Subali, B., \& Sopyan, A. (2012). Penerapan model project based learning dan kooperatif untuk membangun empat pilar pembelajaran siswa SMP. UPEJ Unnes Physics Education Journal, 1(1), 33-37.

Purnomo, E. A., \& Mawarsari, V. D. (2014). Peningkatan kemampuan pemecahan masalah melalui model pembelajaran ideal problem solving berbasis project based learning. Jurnal Karya Pendidikan Matematika, 1(1), 24-31.

Sambada, D. (2012). Peranan kreativitas siswa terhadap kemampuan memecahkan masalah fisika dalam pembelajaran kontekstual. Jurnal Penelitian Fisika dan Aplikasinya (JPFA), 2(2), 37-47.

Simanjuntak, M. P. (2012). Peningkatan pemahaman konsep fisika mahasiswa melalui pendekatan pembelajaran pemecahan masalah berbasis video. Jurnal Pendidikan Fisika, 1(02), 55-60.

Wena, M. (2011). Strategi Pembelajaran Inovatif Kontemporer (Suatu Tinjauan Konseptual Operasional). Jakarta: Bumi aksara.

Widiyatmoko, A., \& Pamelasari, S. D. (2012). Pembelajaran berbasis proyek untuk mengembangkan alat peraga ipa dengan memanfaatkan bahan bekas pakai. Jurnal Pendidikan IPA Indonesia, 1(1).

Yance, R. D. (2013). Pengaruh penerapan model project based learning (PBL) terhadap hasil belajar fisika siswa kelas XI IPA SMA Negeri 1 Batipuh Kabupaten Tanah Datar. Pillar of Physics Education, 1(1), 48-54.

Young, H.D. dan Freedman, R. (2004). Fisika Universitas Edisi Kesepuluh Jilid 2. Jakarta: Erlangga. 